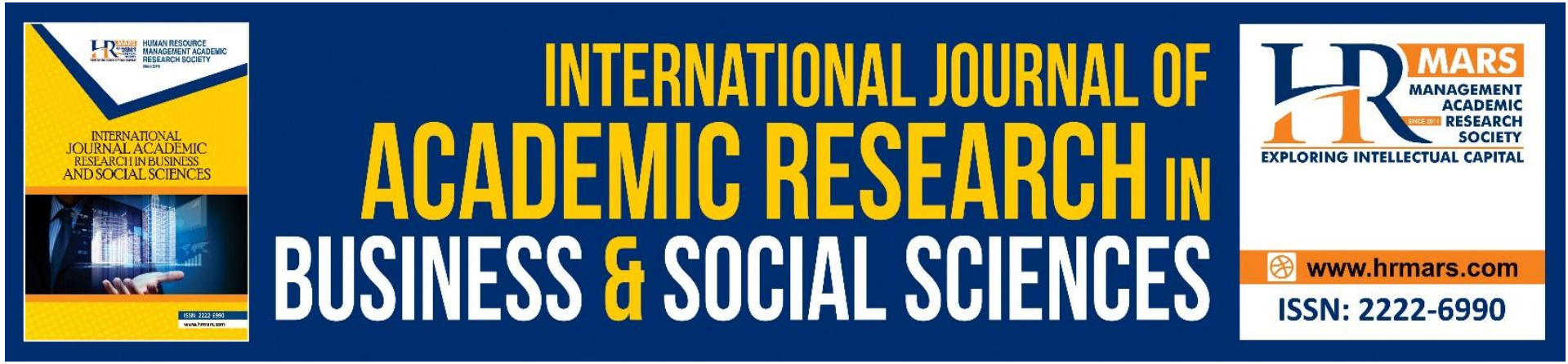

\title{
Factors Influencing Work Stress Among Nurses: Women and Baby Centre Ward \& General Ward KPJ Johor Specialist Hospital
}

Nur Hidayah Zaini, Wan Hasmat Wan Hasan, Afzan Nor Talib, Fariha Aiza Ramly, Rachel Samuel \& Farah Nadzirah Jamrus

To Link this Article: http://dx.doi.org/10.6007/IJARBSS/v11-i6/10323

DOI:10.6007/IJARBSS/v11-i6/10323

Received: 18 April 2021, Revised: 19 May 2021, Accepted: 10 June 2021

Published Online: 20 June 2021

In-Text Citation: (Zaini et al., 2021)

To Cite this Article: Zaini, N. H., Hasan, W. H. W., Talib, A. N., Ramly, F. A., Samuel, R., \& Jamrus, F. N. (2021). Factors Influencing Work Stress Among Nurses: Women and Baby Centre Ward \& General Ward KPJ Johor Specialist Hospital. International Journal of Academic Research in Business and Social Sciences, 11(6), 1230-1238.

Copyright: (c) 2021 The Author(s)

Published by Human Resource Management Academic Research Society (www.hrmars.com)

This article is published under the Creative Commons Attribution (CC BY 4.0) license. Anyone may reproduce, distribute, translate and create derivative works of this article (for both commercial and non-commercial purposes), subject to full attribution to the original publication and authors. The full terms of this license may be seen at: http://creativecommons.org/licences/by/4.0/legalcode

Vol. 11, No. 6, 2021, Pg. 1230 - 1238

http://hrmars.com/index.php/pages/detail/IJARBSS

JOURNAL HOMEPAGE

Full Terms \& Conditions of access and use can be found at http://hrmars.com/index.php/pages/detail/publication-ethics 


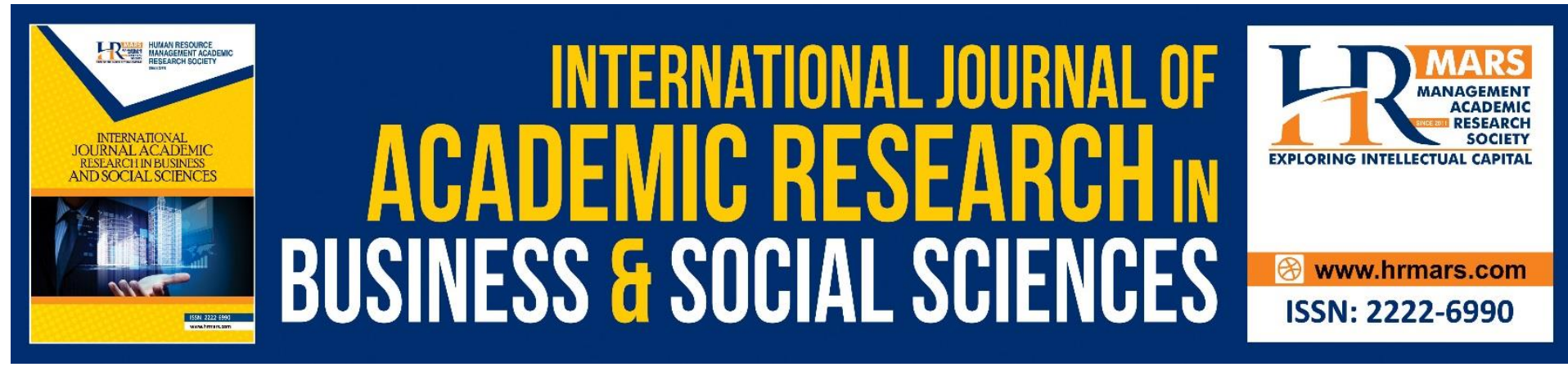

\title{
Factors Influencing Work Stress Among Nurses: Women and Baby Centre Ward \& General Ward KPJ Johor Specialist Hospital
}

\author{
Nur Hidayah Zaini ${ }^{1}$, Wan Hasmat Wan Hasan², Afzan Nor \\ Talib $^{3}$, Fariha Aiza Ramly ${ }^{4}$, Rachel Samuel ${ }^{5}$ \& Farah \\ Nadzirah Jamrus ${ }^{6}$ \\ ${ }^{1-5}$ Faculty of Business and Management, Universiti Teknologi MARA (UiTM) Melaka, \\ Malaysia, ${ }^{6}$ Faculty of Computer Sciences \& Mathematics, Universiti Teknologi MARA \\ (UiTM) Melaka, Malaysia

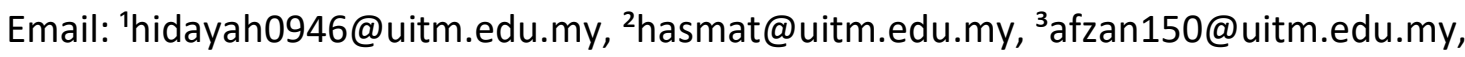 \\ 4faizaramly@uitm.edu.my \& rachelsam@uitm.edu.my, ${ }^{6}$ fnadzirah@uitm.edu.my
}

\begin{abstract}
This study was conducted to investigate whether excessive workload factor, poor work environment factor, lack of social support factor and shortage of manpower factor will influence work stress among nurses at KPJ Johor Specialist Hospital. In this study, the questionnaire used is adopted from Fitzgibbon (2016), Beh and Loo (2012) and Konstantinos and Christina (2008).

The questionnaires were distributed to 80 nurses from Women and Baby Centre Ward and General Ward at KPJ Johor Specialist Hospital by using the convenience sampling technique. The software used to analyse the collected data is SPSS. By using correlation analysis, it is found that there is significance and positive correlation between work stress and the four factors. From the correlation analysis, excessive workload factor $(r=0.553)$ and shortage of manpower factor (0.564) were the strongest positively related to work stress among KPJ nurses. The multiple regression analysis also used in this study revealed that the four factors are significant in explaining the dependent variable; working stress $(F=11.877, p<0.05)$.

Keywords: Excessive Workload, Poor Work Environment, Lack of Social Support, Shortage of Manpower, Work Stress
\end{abstract}

\section{Introduction}

Malaysia is widely known as it provides an efficient and widespread system of healthcare (Chua, 2018). It comprises two-tier health care systems which are the government run universal healthcare system and the coexisting private health care system. Malaysian's healthcare system can also be categorized into the public and private sector.

Nurses work as part of a team of professional as well as medical staff that includes doctors, social workers and many more. Thus, they usually plan and provide medical as well as nursing care to patients in hospital, at home or other settings who are suffering from illness. Hence, 
nurses perform a wide range of tasks to provide adequate nursing services, which makes them a key person in assisting doctors and patients. Despite the responsibility of the nurses to monitor patients' condition, nurses are also needed to observe and provide care for patients and families who are suffering and where emotions are heightened (Heffernan, 2010)

Today's dynamic life is leading to job stress among employees at the workplace. In fact, work stress is widely known as the psychological state which represents an imbalance as well as inconsistencies between employee's perceptions on demand towards their abilities to cope with those demands. It also can be viewed as facing hurdles in life by an individual due to demands, constraints or opportunities. Sometimes, working is stressful and can easily disrupt a person's work-life balance. According to Johan, et. al. (2017) stress is widely known as everyday life's reality because everyone suffers from different situations and circumstances. As we can see, nurses have been nominated as one of the highest stress professions because the nature of the job itself gives a huge impact towards nurses' health mentally and physically. Heathfield (2019) stated that the profession as nurses is full of stress and challenge where nurses would be given a task to provide emotional support as well as relieving stress of dying and crying patients

Tan Sri Lee Lam Thye, previous chairman of National Institute of Occupational Safety and Health (NIOSH) stated that occupational stress among hospital workers is renowned as a serious issue among the healthcare industry in Malaysia. He also clarifies that work stress leads to the increased number of commuting accidents involving nurses in 295 cases and followed by the healthcare assistants in 92 cases. This is further supported by Dr. Dzulkefly Ahmad, the previous Health Minister who stated that 4.2 million Malaysians are suffering from mental health issues and 2.1 million women out of it have the high tendency to suffer mental illness. He also said that a total of 57,570 Malaysian women are seeking for treatment for mental illness at the government hospital from 2010 to 2017 (The Star Online, 2018)

According to Katulka (2018), there is a study conducted by Kronos Incorporated in 2017, 257 registered nurses working in United States hospitals were surveyed. The results show that 85 percent of nurses were feeling fatigue with their work while 63 percent were experiencing job burnout at the workplace. At the same time, it shows that 41 percent of nurses prefer to change workplace in the past year due to work stress. Other than that, it is also stated that 90 percent of nurses prefer to leave the current workplace to seek a better work environment in the future.

Work stress among healthcare professionals is very expensive because it would create a huge impact on nurses in various forms such as tiredness, harsh behaviour, anxiety, increase of blood pressure, lack of self- confidence, lack of job satisfaction as well as decrease in efficiency (Najimi, 2012). Work stress among nurses also causes depression, isolated from patients, absences, and decreased qualifications.

According to Malaysia's Healthiest Workplace report (AIA Vitality Survey, 2018), Malaysian employees have become increasingly affected by mental issues over the years. In fact, it will lead to staff absenteeism and turnover, which negatively impact the productivity and performance of the company if the issue is not addressed. More importantly, it revealed that the depression rates for at least one dimension of work stress are broadly similar to those of 2017 with Malaysia showing some improvement as the rates decrease from 53\% in 2017 to $50.2 \%$ in 2018 . This is because when there is high staff engagement at the workplace, it will eventually reduce the stress levels. It also said that staff with a flexible work schedule tend to pose lower stress levels.

Hence, this research is to study if excessive workload, poor work environment, lack of social 
support and shortage of manpower would influence work stress among nurses at KPJ Johor specialist Hospital.

\section{Method}

Descriptive statistics was used with causal types of investigation where KPJ Johor Specialist Hospital was chosen in the study. The research was conducted in a non-contrived setting where the data was collected in the normal setting of work at the KPJ Johor Specialist Hospital. From a total of 100 nurses in the department of Women and Baby Centre and General Ward in KPJ Johor Specialist Hospital, 80 nurses were chosen, and a convenience sampling technique was used in distribution of the questionnaires. The studies were focused on nurses who are currently working at two different departments which are Women and Baby Centre and General Ward at KPJ Johor Specialist Hospital. An excessive workload, shortage of manpower, lack of social support and poor working environment are among the variables used to identify the factors affecting work stress.

The questionnaires were self-constructed and adapted from various sources mainly from Fitzgibbon (2016), Beh and Loo (2012) and Konstantinos and Christina (2008). Each variable shows an acceptable and good reliability; work stress (0.880), excessive workload (0.781), poor work environment (0.848), lack of social support (0.881) and shortage of manpower (0.848). Data analysis was conducted to see the strength of association and which factors are most dominant affecting work stress among nurses. The Statistical Package for Social Science for Windows, SPSS was used to analyze the data and obtain answers to the research questions.

\section{Results and Discussion}

Table 1.0 Frequency Analysis

\begin{tabular}{|c|c|c|c|}
\hline & & Frequency & Percentage (\%) \\
\hline \multirow{2}{*}{ Gender } & Male & 6 & 7.5 \\
\hline & Female & 74 & 92.5 \\
\hline \multirow{3}{*}{ Age } & $20-29$ & 41 & 51.2 \\
\hline & $30-39$ & 18 & 22.5 \\
\hline & 40 and above & 21 & 26.3 \\
\hline \multirow{3}{*}{ Race } & Malay & 59 & 73.8 \\
\hline & Indian & 2 & 2.5 \\
\hline & Chinese & 19 & 23.8 \\
\hline \multirow{2}{*}{ Marital Status } & Single & 31 & 38.8 \\
\hline & Married & 49 & 61.3 \\
\hline \multirow{4}{*}{ Educational Level } & Diploma in & & 91.3 \\
\hline & Nursing & $\begin{array}{l}13 \\
7\end{array}$ & 8.8 \\
\hline & Degree in Nursing & $\gamma$ & \\
\hline & TOTAL & 80 & 100 \\
\hline
\end{tabular}


Based on Table 1.0 Frequency Analysis, it has been clearly stated that the respondents are from Women and Baby Centre Ward as well as General Ward nurses at KPJ Johor Specialist. About 6 of the respondents are contributed by the males (7.5\%). While, the balance of 74 of the respondents were females (92.5\%). As for the ages, out of 80 respondents, 21 of respondents are at 40 and above (26.3\%) and the balances are nurses aged 30-39 (22.5\%). Therefore, the majority of the respondents are aged 20-29 (51.2\%). Besides that, for marital status, it has been shown that 31 of the respondents were single $(38.8 \%)$ and the remaining of 49 of the respondents were married (61.3\%). Other than that, as for races, it reveals that the majority of respondents were Malay (73.8\%). While, the minority of respondents were dominated by Chinese (2.5\%). The remaining of $23.8 \%$ were Indian respondents. Aside from that, the data collected through surveys show that the respondents come from different educational level either Diploma in Nursing or Degree in Nursing. Based on the respondents' background, it shows that 73 respondents have a Diploma in Nursing (91.3\%) and followed by 7 respondents have Degree in Nursing (8.8\%).

Table 2.0 Reliability Analysis

\begin{tabular}{cccc}
\hline Variable & $\begin{array}{c}\text { Cronbach's } \\
\text { Alpha }\end{array}$ & No. of items & $\begin{array}{c}\text { Strength of } \\
\text { Association }\end{array}$ \\
\hline Work Stress & 0.880 & 10 & Acceptable \\
Excessive Workload & 0.781 & 10 & Acceptable \\
Poor Work Environment & 0.848 & 10 & Acceptable \\
Lack of Social Support & 0.881 & 10 & Acceptable \\
Shortage of Manpower & 0.848 & 10 & Acceptable \\
\hline
\end{tabular}

As referred to rule of thumb by Tavakol and Dennick (2011), reliabilities that less than 0.60 are considered to have a poor strength association, those in 0.70 ranges have an acceptable strength of association and above 0.80 is considered good in the strength of association. Based on the table above, a reliability test has been carried out for five variables. All the alpha value of the five variables is greater than 0.7 which meant these variable consistent to measure the reliability of this research.

Table 3.0 Correlation Analysis

\begin{tabular}{llllll}
\hline & EW & PWE & LSS & SM & WS \\
\hline $\begin{array}{l}\text { Pearson } \\
\text { Correlation }\end{array}$ & $.553^{* *}$ & $.396^{* *}$ & $.398^{* *}$ & $.564^{* *}$ & 1 \\
Sig. (2-tailed) & 0.000 & 0.000 & 0.001 & 0.000 & \\
$\mathrm{~N}$ & 80 & 80 & 80 & 80 & 80 \\
\hline
\end{tabular}

** Correlation is significant at the 0.01 level (2-tailed)

Remarks: EW $=$ Excessive Workload; PWE $=$ Poor Work Environment; LSS $=$ Lack of Social Support; SM = Shortage of Manpower, WS = Work Stress

Table 3.0 briefly explained that there is significance, positive and moderate correlation between work stress and excessive workload $(r=0.553, p<0.05)$. While, there is a significant, positive, and low correlation between work stress and poor work environment $(r=0.396, p<$ $0.05)$. There is a significant, positive, and low correlation between work stress and lack of social support $(r=0.398, p<0.05)$. While, there is a significant, positive, and moderate correlation between work stress and lack of shortage of manpower $(r=0.564, p<0.05)$. In conclusion the strongest relationship is represented between shortage of manpower and 
work stress. Then followed by other factors: excessive workload, lack of support system and poor work environment.

Table 4 Multiple Regression Analysis

\begin{tabular}{lll}
\hline $\begin{array}{l}\text { Dependent Variable } \\
\text { Work Stress }\end{array}$ & \\
\hline Independent variable & Standard Coefficient & Sig. \\
Excessive Work & .294 & .025 \\
Poor Work Environment & .171 & .166 \\
Lack of Social Support & -.172 & .259 \\
Shortage of Manpower & .400 & .008 \\
F-Value & 11.877 & \\
Sig. & 0.000 & \\
R-Square & .388 & \\
Adjusted R-square & .355 & \\
\hline
\end{tabular}

Table 4 Multiple Regression Analysis shows that the $\mathrm{R}^{2}$ of 0.388 implies that all the independent variables (excessive workload, poor work environment, shortage of manpower, and lack of social support) explain $38.8 \%$ percent of the variance in the dependent variable (work stress). 61.2\% percent of the variance in the work stress is explained by others. This indicates that there are other independent variables which are not included in this study and could further strengthen the regression equation.

F-test is significant based on the $p$-value (given by F-Sig.) below 0.05 . Hence, the linear model is overall valid $(F=11.877, P<0.05)$. It indicates that the F-value is significant. Hence all the independent variables used in this research are significant in explaining the dependent variable; work stress.

As excessive workload increases by one standard deviation, work stress increases by 0.294 of a standard deviation. As a poor work environment increases by one standard deviation, work stress increases by 0.171 of a standard deviation. As shortages of manpower increase by one standard deviation, work stress increases by -0.172 of a standard deviation. As lack of social support increases by one standard deviation, work stress increases by one standard deviation 0.400 of a standard deviation.

In fact, the most important independent variable would be the shortage of manpower as the magnitude of corresponding standardized coefficient is the largest, with a beta weight of 0.400 . While, the weakest variable would be lack of social support with beta weight of -0.172 . Poor work environment and excessive workload do not explain the variance in work stress significantly.

\section{Discussion}

This research was purposeful to examine and determine the factors influencing work stress among women and baby centre ward as well as general ward nurses at KPJ Johor Specialist Hospital. Prior research indicates that numerous elements can influence work stress among women and baby centre wards as well as general ward nurses at KPJ Johor Specialist Hospital, including excessive workload, poor work environment, lack of social support and shortage of manpower.

Table 3 briefly stated that there is significant, positive and moderate correlation between excessive workload and work stress. $(r=0.553, p<0.05)$. Hence, excessive workload has a positive relationship toward work stress among nurses at KPJ Johor Specialist Hospital. This 
finding can be supported through study conducted by Kokoroko and Sanda (2019) between excessive workload and work stress. The result of the study clearly stated that there was a significant positive correlation between excessive workload and job stress $(r=0.37, p<0.01)$ among Ghanaian OPD nurses.

Ayomi et al. (2015) stated that there was no significant relationship between work environment and work stress among inpatient ward nurses of Yowari Hospital Sentani, Jayaputra district with a p-value of 0.606 . While a study conducted by Kokoroko and Sanda (2019) stated that the social support does not significantly correlate with the level of job stress. But on the other hand, Table 3 depicted that the correlation between poor work environment and work stress among nurses at KPJ Johor Specialist Hospital $(r=0.396, p<$ 0.05 ) is significantly low positive. Similarly for correlation between lack of social support and work stress $(r=0.398, p<0.05)$ among nurses at KPJ Johor Special also shows the same result. These findings are in contrast since the study was conducted on different populations which were among nurses at KPJ Johor Specialist Hospital.

While the relationship between shortage of manpower and work stress among nurses at KPJ Johor Specialist Hospital showed there exists significant positive and moderate correlation with $r=0.564, p<0.05$. According to Moustaka and Constantinidis (2010), the nature of nursing is one of the major serious stresses that are associated with work stress in nursing. This is because nurses tend to confront challenging work tasks, shift work schedules, encounter stressful working environments, understaffing as well as difficulty in handling patients.

\section{Conclusion}

The results show that all the four factors are significant and contribute to the work stress among nurses at women and baby centre ward and general ward at KPJ Johor Specialist Hospital. It shows that excessive workload and shortage of manpower have been nominated as major factors that influence work stress among nurses at KPJ Johor Specialist Hospital compared to others. It is supported by the study conducted by Salma, J. et al. (2017) between the shortage of manpower and work stress. There are about 59 or $64 \%$ respondent strongly agreed while the balance of 32 or $34 \%$ respondent disagreed with the statement that shortage of staff nurses causes them to experience stress. There is an overwhelming that the majority of nurses (64\%) believed the shortage of staff causes stress to them.

Future researchers should expand the research respondent to another hospital or include government hospital too. This will widen the scope of research and add more respondents. Hence, this will make the study more reliable.

\section{Acknowledgements}

The authors gratefully acknowledge the help of the Universiti Teknologi MARA Cawangan Melaka in providing the TEJA Fund research grant. The authors are also thankful to everyone in KPJ Johor Specialist Hospital especially all the nurses for lending hands and information to complete our research.

\section{References}

Alenezi, A. M., Aboshaiqah, A., \& Baker, O. (2018). Work-related stress among nursing staff working in government hospitals and primary health care centres. International Journal of Nursing Practice, 24(5), e12676. https://doi.org/10.1111/ijn.12676 
Alias, N. E., Sehat, N. S., Othman, R., Marmaya, N. H., \& Koe, W. L. (2019). Determinants of Job Stress in Affecting Employees'Life: A Study on the Malaysian Manufacturing Sector. International Journal of Academic Research in Business and Social Sciences, 9(7), 12121225.

Arbabisarjou, A., Ghoreishinia, G., Zare, S., Shahrakipour, M., \& Chalileh, J. (2017). Study of Job Stress among Nurses Working in Teaching Hospitals. Der Pharmacia Lettre

Beh, Loo-See. (2012). Job Stress and Coping Mechanisms among Nursing Staff in Public Health Services. International Journal of Academic Research in Business and Social Sciences. 02.

Carayon, P., Hundt, A., Alvarado, C., Springman, S., \& Ayoub, P. (2006). Patient Safety in Outpatient Surgery: The Viewpoint of the Healthcare Providers. Ergonomics. 49. 47085. 10.1080/00140130600568717.

Chua, C. (2018). The Future of Malaysian Healthcare. Leaderonomics.com. Retrieved November 9, 2018 from https://leaderonomics.com/business/mpc-malaysianhealthcare

Dobnik, M., Maletič, M., \& Skela-Savič, B. (2018). Work-Related Stress Factors in Nurses at Slovenian Hospitals - A Cross-sectional Study. Zdravstveno varstvo, 57(4), 192-200. https://doi.org/10.2478/sjph-2018-0024

Fitzgibbon, S. H. (2016). Work Stress Among Nurses in Ontario. Industrial Relation Center.

Heathfield, M. S. (2019). Understanding Stress and How It Affect the Workplace. Retrieved May, 3, 2019 from The Balance Careers https://www.thebalancecareers.com/understanding-stress-and-how-it-affects-theworkplace 1919200

Hussein, J., Ismail, A., \& Jamil, A. T. (2012). Factors associated with organizational stress among intensive care unit healthcare workers, in Somalia Hospital. Malaysian Journal of Public Health Medicine. 12. 57-66.

Johan, Salma \& Sarwar, Hajra \& Majeed, Iram. (2017). To Identify the Causes of Stress among Nurses Working in Intensive Care Unit of Ittefaq Hospital Lahore. International Journal of Social Sciences and Management. 4. 96. 10.3126/ijssm.v4i2.17159.

Joibi, N. (2018). Help Healthcare Workers Deal with Stress. The Star. Retrieved July 2, 2018, from https://www.thestar.com.my/metro/metro-news/2019/07/02/help-healthcareworkers deal-with-stress-says-niosh

Katulka, L. (2018). Nurse Burnout Statistics-and How to Avoid Becoming One. Berxi. Retrieved July 11, 2018, from https://www.berxi.com/resources/articles/nurse-burnout statistics/

Cercenis, K. I. M. (2012). Stress Related Work Environment Factors: Nurses Survey. International Journal of Collaborative Research on Internal Medicine \& Public Health, Vol.4 No. 6, 1150-1157

Kokoroko, E., \& Sanda, M. (2019). Effect of Workload on Job Stress of Ghanaian OPD Nurses: The Role of Co-Worker Support. Safety and Health at Work. 10. 10.1016/j.shaw.2019.04.002.

Moustaka, E., \& Constantinidis, T. C. (2010). Sources and Effect of Work-Related Stress in Nursing. Health Science Journal, 210-216

Najimi, A., Goudarzi, A. M., \& Sharifirad, G. (2012). Causes of Job Stress in Nurses: A crosssectional study. Iranian Journal of Nursing and Midwifery Research, 17(4), 301-305.

Nakakis, K., \& Ouzouni, C. (2008). Factors influencing stress and job satisfaction of nurses working in psychiatric units: A research review. Health Science Journal. 2.

Nakasis, K., \& Ouzouni, C. (2008) Factors influencing stress and job satisfaction of nurses 
working in psychiatric units: a research review. Health Science Journal 2 (4), 183-195

Rawal, C. N., \& Pardeshi. (2014). Job Stress Causes Attrition among Nurses in Public and Private Hospitals. IOSR Journal of Nursing and Health Science. 3. 42-47. 10.9790/195903224247.

Ridzuan, A. N. A. A., Zakaria, N. Z., Eshak, E. S., Jidi, M. M., Bakar, N. A., Jamian, N. F., \& Zani, A. M. (2017). Occupational Stress on Job Performance of Office Work-Based Employees in Malaysia's Port. International Journal of Academic Research in Business and Social Sciences, 7(11), 1321-1331.

Samat, M. F., Zaki, F. S. M., Rasidi, E. R. M., Roshidi, F. F., \& Ghul, Z. H. (2020) Emotional Intelligence, Social Supports, Technology Advancement, Work Condition and Work-Life Balance among Employees.

Tahir, N. K. M., \& Hussein, N. (2018). Job demands and Job Resources: A study of nurses at a General Hospital in Malaysia. International Journal of Academic Research In Business And Social Sciences, 8(11).

The Star Online. (2018). 29\% of Malaysians Have Mental Problems Due to Stress. Retrieved August 5, 2018, from https://www.thestar.com.my/news/nation/2018/08/05/lee-lamthye more-msians-will-suffer-from-depression-by-2020-due-to-stress 